\title{
Protective Effect of White-Skinned Sweet Potato (/pomoea batatas L.) from Indonesia on Streptozotocin-Induced Oxidative Stress in Rats
}

\author{
Moch. Saiful Bachri, Hye won Jang ${ }^{1}$, Jongwon Choi ${ }^{2}$ and Jong-Ok Park ${ }^{3}$. \\ Faculty of Pharmacy, Ahmad Dahlan University, Yogjakarta 55164, Indonesia \\ ${ }^{1}$ Division of Endocrinology \& Metabolism, Samsung Medical Center, Sungkyunkwan University School of Medicine, Seoul 135-710, Korea \\ ${ }^{2}$ College of Pharmacy, Kyungsung University, Busan 608-736, Korea \\ ${ }^{3}$ Department of Chemistry, Kyungsung University, Busan 608-736, Korea
}

Received February 16, 2010 /Accepted November 12, 2010

\begin{abstract}
Sweet potato (Ipomoea batatas L.) is widely used in Indonesia and other countries as a traditional medicine for the treatment of diabetes mellitus (DM). The MeOH extract of white skinned sweet potatoes (WSSP) was administered orally in doses of 100 and $200 \mathrm{mg} / \mathrm{kg}$ body weight in streptozotocin (STZ)-induced diabetic rats. Experimental diabetes was induced by a single dose of STZ (45 mg/ $\mathrm{kg}$, i.p.) injection. Oxidative stress was measured by tissue lipid peroxide (LPO) levels, serum aspartate transaminase (AST), alanine transaminase (ALT), total triglyceride (TG), total cholesterol (TC) and by antioxidative enzymatic activities of superoxide dismutase (SOD), catalase (CAT), glutathione peroxidase (GPx) and glutathione S-transferase in the liver. An increase in blood glucose, LPO level, AST, ALT, TG and TC levels was observed in the STZ-induced diabetic rats. Administration of $\mathrm{MeOH}$ extract of WSSP at a dose of $200 \mathrm{mg} / \mathrm{kg}$ for two weeks caused a significant reduction in blood glucose, LPO levels, AST, ALT, TG and TC levels in the STZ-induced diabetic rats. Furthermore, oral administration of $\mathrm{MeOH}$ extract showed significant improvement in the activities of antioxidant enzymes (SOD, GPx, and CAT) compared to STZ-induced diabetic rats. In conclusion, the obtained results clearly indicate the role of oxidative stress in the induction of diabetes, and that the protective effects of $\mathrm{MeOH}$ extracts of WSSP could be used to benefit diabetic patients.
\end{abstract}

Key words : Oxidative stress, white-skinned sweet potato, diabetes mellitus, streptozotocin

Introduction

Oxidative stress is postulated playing an important role in chronic complications of diabetes and be associated with increased lipid peroxidation [17]. Streptozotocin (STZ) is usually used to induce diabetes mellitus (DM) in research used animal through its toxic effects on pancreatic beta-cells $[34,44]$. The generation of reactive oxygen species causing oxidative damage is associated with the cytotoxic action of STZ [35].

DM is a chronic metabolic disorder which now afflicts $3 \%$ of the world population. Based on individual etiologies, $\mathrm{DM}$ is classified into two types (type 1 and type 2). Type 2 diabetes is diagnosed in around $95 \%$ of diabetic patients [2]. Insulin resistance and insulin deficiency which can cause hyperglycemia is a major feature of type 2 diabetes [19]. Therefore, maintenance of blood glucose level is a key strategy in treating patients with type 2 diabetes.

*Corresponding author

Tel : +82-51-663-4633, Fax : +82-51-628-4628

E-mail : gopark@ks.ac.kr
Current oral anti-diabetic agents, which include insulin releasers, insulin sensitizers and a-glucosidase inhibitors, have modest efficacy and limited of modes of action. Also DM manifested by experimental animal models exhibit high oxidative stress due to persistent and chronic hyperglycemia, which thereby depletes the activity of antioxidative defense system [3]. Increased oxidative stress and changes in antioxidant capacity, observed in both clinical and experimental DM are thought to be the etiology of diabetic complications [4]. In diabetes there are significant changes such as increased lipid peroxidation, dyslipidemia and irregularities in the metabolism of proteins, lipids and carbohydrates. Lipid is known to impair the exocrine pancreas by damaging the endothelium of blood vessels [41]. In addition, recent anti-diabetic drugs usually have adverse side effects, decreased efficacy over time, ineffectiveness against some long-term diabetic complications and low cost-effectiveness [11]. Therefore, discovery and development of novel drugs for DM is still needed.

Sweet potato (Ipomoea batatas L.) is a represents an economically important crop in tropical, subtropical and warm 
temperate regions. The world production of sweet potato was estimated at $129.4 \mathrm{Mt}$ in 2005 , of which more than $88 \%$ were from Asian countries, particularly China, with 107.1 Mt [8]. The storage roots contain a high amount of starch, which is as high as $30 \%$ of fresh weight for some cultivars. They are used as staple food, raw material for alcohol production, and animal feed. Stems and foliage are also used as forage. Several studies have reported on the antioxidant activity $[16,18,23,39]$, and anti diabetic activity $[5,32,40]$ of sweet potato extracts. Sweet potatoes have been used as traditional medicine in Indonesia for DM [30]. Recent studies on purple sweet potato showed attenuating in oxidative stress and inflammatory respond [45]. Nevertheless, little work has been done to explore white-skinned sweet potato (WSSP) in oxidative stress. The object of this study was to explore that WSSP protected rats liver from STZ-induced injury by attenuating oxidative stress, since STZ - induced oxidative stress results from the generation of free radical in the liver. We presented the protective effect of liver injury from STZ - induced oxidative stress by the methanol extract of WSSP in this paper.

\section{Materials and Methods}

\section{Animals}

Male Sprague Dawley (SD) $(200 \pm 10 \mathrm{~g})$ rats were purchased from Hyochang Science, Daegu, Korea. All animals were maintained in the institutional animal facility and handled according to the guidelines of the pharmacology department, college of pharmacy, Kyungsung University, Republic of Korea. Animals were acclimatized for a week before starting the experiments with condition, light/dark cycle: $12 \mathrm{hr}$, humidity: $46-60 \%$, temperature $22 \pm 0.5^{0} \mathrm{C}$ in university animal room and with free access to rodent food and water ad libitum throughout the experimental period.

\section{Preparation of the extract}

Fresh storage roots of white-skinned sweet potato (Ipomoea batatas L.) were purchased from a local market in Yogyakarta Indonesia. Samples were processed into extract in Biology Pharmacy Department of faculty of Pharmacy, Ahmad Dahlan University, Yogyakarta, Indonesia. The samples were sliced, dried and ground into powder. $8 \mathrm{~kg}$ of powder was dissolved three times in 8 liters of methanol for 3 days, filtered, and evaporated to obtain the crude methanol extract $(16 \mathrm{~g})$. The crude methanol extracts freeze dried for 3 days to get $10 \mathrm{~g}$ dried powder.

\section{Animal groups and experimental treatment}

Animals were divided into five groups with five animals in each group; Group I, normal rats treated with the vehicle only (tween:saline); Group II, control rats treated with the vehicle and a single dose of STZ $45 \mathrm{mg} / \mathrm{kg}$; Group III, rats treated with STZ $45 \mathrm{mg} / \mathrm{kg}$ and MeOH extract of WSSP (100 $\mathrm{mg} / \mathrm{kg}$ ); Group IV, rats treated with STZ $45 \mathrm{mg} / \mathrm{kg}$ and $\mathrm{MeOH}$ extract of WSSP $(200 \mathrm{mg} / \mathrm{kg})$; Group V, rats treated with STZ $45 \mathrm{mg} / \mathrm{kg}$ and glimepiride $0.5 \mathrm{mg} / \mathrm{kg}$. After oral administration with $\mathrm{MeOH}$ extract and glimepiride as pre-experiment for 2 weeks, rat was injected with STZ (Sigma Chemical Co. St. Louis, MO, USA. $45 \mathrm{mg} / \mathrm{kg}$ ) in citrate buffer ( $\mathrm{pH} 4.5$ ) by a single intraperitoneal injection to make diabetes rats. Normal rats were injected with saline. Three days after STZ treatment, development of diabetes was confirmed by measuring the blood glucose levels using glucose reagent strips (Glucometer 4 Ames, Bayer Diagnostics). Rats with fasting blood glucose levels of 250 $\mathrm{mg} / \mathrm{dl}$ or higher were considered to be diabetic. The $\mathrm{MeOH}$ extract and glimepiride were orally administered daily during the 2 weeks after STZ induced (post experiment). After completion of the treatments, the animals were sacrificed using carbon dioxide as anesthesia. Blood was collected directly from the abdominal vein, and separated to obtain serum. Liver were removed, cleaned and washed in ice-cold normal saline for biochemical study.

\section{Determination of liver antioxidant activity of WSSP}

Serum AST and ALT were determined according to the method Reitman and Frankel [26], total triglyceride (TG) was assayed according to the method of Richmond [28], total cholesterol (TC) was determined according to the method of McGowan [21], using a diagnostic kit from Asan Inc., Korea. The level of lipid peroxidation was measured as malondialdehyde (MDA), a thiobarbituric acid reactive substance (TBARS), using 1'1' $1^{\prime} 3^{\prime}$-tetra methoxypropane as the standard [22]. Superoxide dismustase (SOD) activity was assayed according to the method of Marklund and Marklund [20]. This assay procedure involved the inhibition of epinephrine auto-oxidation to adenochrome in alkaline medium ( $\mathrm{pH}$ 10.2) which is markedly inhibited by the presence of SOD. Epinephrine was added to the assay mixture, containing tissue supernatant with the change in the extinction coefficient observed at $480 \mathrm{~nm}$ using spectrophotometer. 
Catalase (CAT) changes $\mathrm{H}_{2} \mathrm{O}_{2}$ into water. The CAT activity in tissue was measured at $240 \mathrm{~nm}$ spectrophotometrically by calculating the degradation of $\mathrm{H}_{2} \mathrm{O}_{2}$, the substrate of enzyme [1]. The glutathione peroxidase (GPx) activity was measured according to the method of Paglia and Valentine [24]. The assay was determined by measuring the decrease in the glutathione (GSH) content after incubating the sample in the presence of $\mathrm{H}_{2} \mathrm{O}_{2}$ and $\mathrm{NaN}_{3}$. The glutathione S-transferase (GST) was determined according to the method of Habig [12]. This assay was determined by p-nitrobenzylchloride as the substrate. The absorbance was measured UV-Vis spectrophotometrically at $310 \mathrm{~nm}$.

\section{Assessment of antidiabetic activity on glucose tolerance in rats}

Glucose tolerance test (GTT) was assayed to investigate antidiabetic effect of $\mathrm{MeOH}$ extract of WSSP. The overnight fasted rats were divided into five groups with five rats in each group. Glucose solution $(2 \mathrm{~g} / \mathrm{kg})$ was injected to all groups and $\mathrm{MeOH}$ extract of WSSP were administered. Their fasting blood glucose level of each group was further evaluated at $0,30,60,90,120 \mathrm{~min}$ respectively.

\section{Statistical analysis}

All results are expressed as mean $\pm S D$. Total variation present in a set of data was estimated by one-way analysis of variance (ANOVA) followed by Duncan multiple range post-hoc tests. $p<0.05$ was considered significant.

\section{Results}

\section{Blood glucose level}

Table 1 exhibited the effect of WSSP on the blood glucose level. The mean blood glucose level in normal group (group I) was stable throughout the experimental period. Until 2 weeks administration before STZ induced (pre experiment), all groups showed no significant difference $(p>0.05)$ in blood glucose level. On 7 days after STZ induced, treatments of WSSP showed no significant $(p>0.05)$ reduction in blood glucose compared to diabetic control group. But treatment of glimepiride showed significant $(p<0.05)$ reduction in blood glucose level as compared to diabetic control group. After 2 weeks of treatment (post experiment), diabetic animals had significant responses to $\mathrm{MeOH}$ extract of WSSP compared to diabetic control group. Also glimepiride treated group showed significant $(p<0.05)$ reduction in blood glucose level compared to diabetic control and WSSP group. Oral administration of WSSP at dose of $200 \mathrm{mg} / \mathrm{kg}$ revealed more reduction in blood glucose level compared to WSSP at dose of $100 \mathrm{mg} / \mathrm{kg}$, but statistically no significant difference $(p>0.05)$.

\section{Alanine aminotransferase (ALT) and aspartate aminotrasferase (AST) concentration}

Serum AST and ALT levels can describe the liver function of diabetic animals. Rats intoxicated with STZ alone developed severe hepatocellular injuries with a significant elevation in serum AST and ALT activities when compared to normal group $(p<0.01)$. Oral administration with WSSP at dose of $200 \mathrm{mg} / \mathrm{kg}$ significantly prevented the elevation of serum enzymes compared to diabetic control group $(p<0.01)$ (Fig. 1), but WSSP at dose of $100 \mathrm{mg} / \mathrm{kg}$ showed no significant difference $(p>0.05)$ reduced the AST and ALT levels compared with the diabetic control group.

\section{Total triglyceride and total cholesterol concentration}

The effect of oral administration of $\mathrm{MeOH}$ extract of WSSP in severe diabetic rats was shown in Fig. 2. STZ treatment caused elevation of serum TC and TG compared to normal group. Treatment with $\mathrm{MeOH}$ extract of WSSP at dose of $200 \mathrm{mg} / \mathrm{kg}$ produced significant $(p<0.05)$ reduction not only in TG levels but also in TC levels compared to dia-

Table 1. Effect of $\mathrm{MeOH}$ extract of WSSP on the blood glucose levels in STZ-induced diabetic rats

\begin{tabular}{|c|c|c|c|c|c|c|}
\hline \multirow{3}{*}{ Group } & \multirow{3}{*}{$\begin{array}{c}\text { Dose } \\
(\mathrm{mg} / \mathrm{kg})\end{array}$} & \multicolumn{5}{|c|}{ Blood glucose level (mg/dl) } \\
\hline & & \multicolumn{3}{|c|}{ Before STZ-induced } & \multicolumn{2}{|c|}{ After STZ-induced } \\
\hline & & 0 week & 1 week & 2 week & 1 week & 2 week \\
\hline Normal & & $101.6 \pm 8.53^{\mathrm{a}}$ & $96.3 \pm 7.26^{\mathrm{a}}$ & $100.6 \pm 8.25^{\mathrm{a}}$ & $103.4 \pm 5.26^{\mathrm{c}}$ & $103.9 \pm 11.4^{\mathrm{d}}$ \\
\hline Control & & $97.3 \pm 7.26^{\mathrm{a}}$ & $103.6 \pm 5.48^{\mathrm{a}}$ & $98.7 \pm 7.12^{\mathrm{a}}$ & $530.4 \pm 46.7^{\mathrm{a}}$ & $580.2 \pm 37.8^{\mathrm{a}}$ \\
\hline \multirow[t]{2}{*}{$\mathrm{MeOH}$ ext. } & 100 & $99.8 \pm 8.17^{\mathrm{a}}$ & $98.5 \pm 7.46^{\mathrm{a}}$ & $101.4 \pm 8.16^{\mathrm{a}}$ & $500.2 \pm 39.2^{\mathrm{a}}$ & $531.8 \pm 57.2^{b}$ \\
\hline & 200 & $106.3 \pm 10.4^{\mathrm{a}}$ & $99.3 \pm 8.53^{\mathrm{a}}$ & $106.4 \pm 9.43^{\mathrm{a}}$ & $498.7 \pm 40.3^{\mathrm{a}}$ & $487.8 \pm 31.4^{\mathrm{b}}$ \\
\hline Glimepiride & 0.5 & $103.7 \pm 9.43^{\mathrm{a}}$ & $101.7 \pm 7.46^{\mathrm{a}}$ & $95.6 \pm 8.46^{\mathrm{a}}$ & $390.9 \pm 33.5^{b}$ & $321.4 \pm 25.8^{\mathrm{c}}$ \\
\hline
\end{tabular}

Values are the means \pm SD $(n=5)$. Values within a column with different superscripts are significantly different at $<0.05$ by the Duncan's test. 


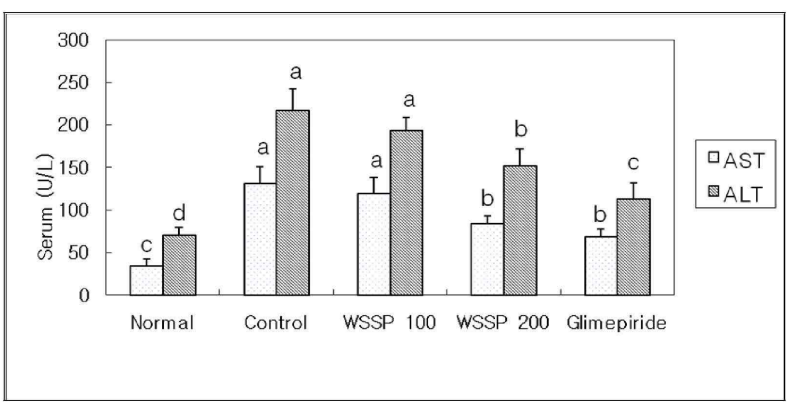

Fig. 1. Effect of MeOH extracts of WSSP on the serum AST and ALP in STZ-induced diabetic rats. AST: aspartate transaminase, ALT: alanine transaminase. Values are the means $\pm S D(n=5)$. Values within a column with different superscripts are significantly different at $<0.05$ by the Duncan test.

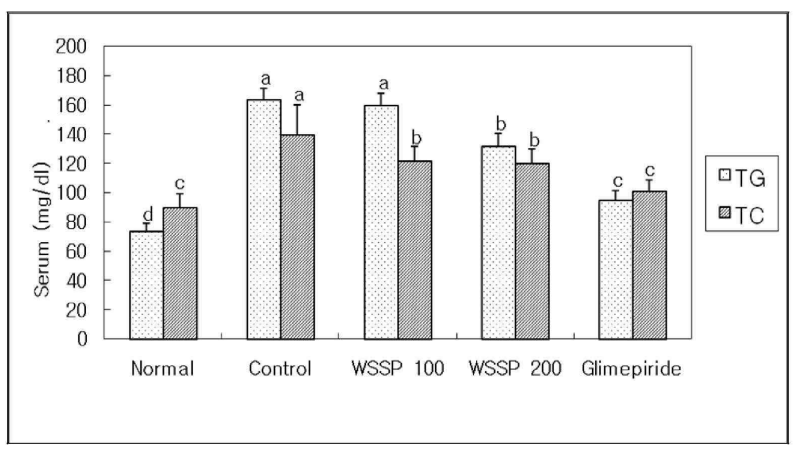

Fig. 2. Effect of MeOH extract of WSSP on the serum TG and TC in STZ-induced diabetic rats. TG: triglyceride, TC: total cholesterol. Values are the means $\pm S D(n=5)$. Values within a column with different superscripts are significantly different at $<0.05$ by the Duncan's test

betic control group, meanwhile $\mathrm{MeOH}$ extract of WSSP at dose of $100 \mathrm{mg} / \mathrm{kg}$ showed significant $(p<0.05)$ reduction only in TG levels compared to control group.

\section{Lipid oxidation activity in liver}

Lipid oxidation has been established as a major mechanism of cellular injury in many biological systems of plant and animal origin. The mechanism involves a process whereby unsaturated lipids are oxidized to form additional radical species as well as toxic by-products that can be harmful to the host system. Polyunsaturated lipids are especially susceptible to this type of damage when in an oxidizing environment and they can react to form lipid peroxides. Polyunsaturated fatty acid peroxides further react to form MDA, which is found in most biological samples including foodstuffs, serum, plasma, tissues and urine, as a result of lipid hydroperoxides, and has become one of the most widely

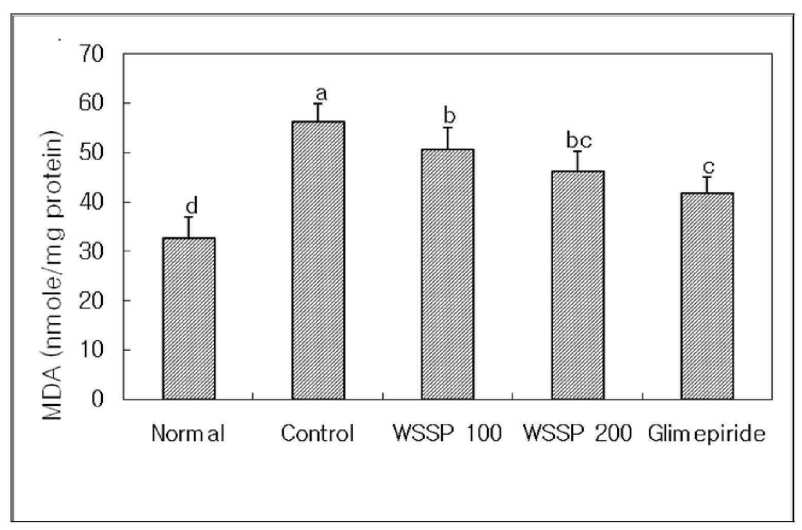

Fig. 3. Effect of MeOH extract of WSSP on LPO in STZ-induced diabetic rats. Values are the means $\pm S D(n=5)$.Values within a column with different superscripts are significantly different at $<0.05$ by the Duncan's test.

reported analytes for the purpose of estimating oxidative stress effects on lipids [15]. Fig. 3 showed the level of malondialdehyde (MDA), a secondary product of lipid peroxidation in the liver tissue homogenate. STZ-induced rats resulting in a significant $(p<0.05)$ increase in MDA levels compared to normal group, whereas oral administration of $\mathrm{MeOH}$ extract of WSSP at dose of 100; $200 \mathrm{mg} / \mathrm{kg}$ exhibited significant $(p<0.05)$ reduction compared with diabetic control group.

\section{Antioxidant enzyme activity in liver}

As shown in Table 2, a significant $(p<0.05)$ decrease in the activities of SOD, CAT and GPX compared to normal group was a notable manifestation of STZ toxicity. The activity of these enzymes were improved significantly $(p<0.05)$ by the administration of $\mathrm{MeOH}$ extract of WSSP at dose of $200 \mathrm{mg} / \mathrm{kg}$ when compared with diabetic control group. Also administration of glimepiride, an insulin releaser, improved these enzymes activities. While, oral administration of $\mathrm{MeOH}$ extract of WSSP at dose of $100 \mathrm{mg} / \mathrm{kg}$ showed no significant difference $(p>0.05)$ reduction in antioxidant enzyme activities compared with diabetic control group.

Table 3 showed that the concentration of GST in animals treated with STZ which were significantly $(p<0.05)$ decreased compared to normal group in liver. Whereas oral administration of $\mathrm{MeOH}$ extract of WSSP and glimepiride showed no significant difference $(p>0.05)$ compared with diabetic control group.

\section{GTT activity in blood}

In order to choose the optimum dose for the normal ani- 
Table 2. Effect of MeOH extract of WSSP on antioxidant enzyme levels in STZ-induced diabetic rats

\begin{tabular}{ccccc}
\hline Group & $\begin{array}{c}\text { Dose } \\
(\mathrm{mg} / \mathrm{kg})\end{array}$ & SOD & Catalase & GPx \\
\hline Normal & & $31.9 \pm 2.17^{\mathrm{a}}$ & $3.82 \pm 0.42^{\mathrm{a}}$ & $2.92 \pm 0.17^{\mathrm{a}}$ \\
Control & & $11.3 \pm 1.23^{\mathrm{d}}$ & $2.16 \pm 0.30^{\mathrm{d}}$ & $1.85 \pm 0.13^{\mathrm{c}}$ \\
MeOH ext. & 100 & $12.4 \pm 2.46^{\mathrm{d}}$ & $2.41 \pm 0.41^{\mathrm{cd}}$ & $2.01 \pm 0.26^{\mathrm{c}}$ \\
& 200 & $18.9 \pm 3.27^{\mathrm{c}}$ & $2.76 \pm 0.25^{\mathrm{bc}}$ & $2.39 \pm 0.18^{\mathrm{b}}$ \\
Glimepiride & 0.5 & $22.6 \pm 3.01^{\mathrm{b}}$ & $3.15 \pm 0.31^{\mathrm{b}}$ & $2.51 \pm 0.27^{\mathrm{b}}$ \\
\hline
\end{tabular}

Superoxide Dismustase (SOD, U/mg protein); Glutathione Peroxidase (GPx, NADPH oxidized/min/mg protein); Catalase (CAT, $\mathrm{nmol}$ of $\mathrm{H}_{2} \mathrm{O}_{2}$ consumed/min/mg protein).

Values are the means $\pm \mathrm{SD}(\mathrm{n}=5)$. Values within a column with different superscripts are significantly different at $<0.05$ by the Duncan's test.

Table 3. Effect of $\mathrm{MeOH}$ extract of WSSP on Glutathion-STransferase in STZ-induced diabetic rats

\begin{tabular}{ccc}
\hline Group & $\begin{array}{c}\text { Dose } \\
(\mathrm{mg} / \mathrm{kg})\end{array}$ & $\begin{array}{c}\text { Glutathion-S-transferase } \\
(\mathrm{nmol} / \mathrm{min} / \mathrm{mg} \text { protein })\end{array}$ \\
\hline Normal & & $216.4 \pm 39.8^{\mathrm{a}}$ \\
Control & & $123.8 \pm 21.7^{\mathrm{b}}$ \\
MeOH ext. & 100 & $131.6 \pm 30.9^{\mathrm{b}}$ \\
& 200 & $137.9 \pm 25.2^{\mathrm{b}}$ \\
Glimepiride & 0.5 & $135.2 \pm 40.7^{\mathrm{b}}$ \\
\hline
\end{tabular}

Values are the means $\pm S D(n=5)$. Values within a column with different superscripts are significantly different at $<0.05$ by the Duncan's test

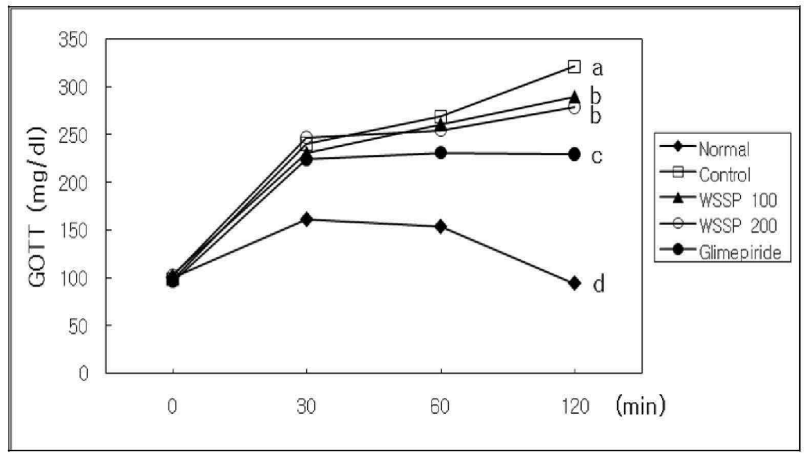

Fig. 4. Effect of $\mathrm{MeOH}$ extract of WSSP on GOTT levels in STZ-induced diabetic rats. Values are the means \pm SD $(n=5)$. Values within a column with different superscripts are significantly different at $<0.05$ by the Duncan's test.

mals, $\mathrm{MeOH}$ extracts of WSSP at 100 and $200 \mathrm{mg} / \mathrm{kg}$ dose were evaluated on glucose tolerance in normal rats along with the standard drug glimepiride $(0.5 \mathrm{mg} / \mathrm{kg})$. A reduction of $13 \%$ in blood glucose levels was observed within 120 min on GTT by the dose of $200 \mathrm{mg} / \mathrm{kg}$. Whereas, at dose of $100 \mathrm{mg} / \mathrm{kg}$ showed reduction of $9.8 \%$. The reductions in both the WSSP groups showed statistically significant difference compared to diabetic control group $(p<0.05)$. However, both the $\mathrm{MeOH}$ extracts of WSSP at dose of 100 and 200 $\mathrm{mg} / \mathrm{kg}$ showed no significant difference $(p>0.05)$ in blood glucose levels after $120 \mathrm{~min}$ treatment (Fig. 4).

\section{Discussion}

Imbalance between the reactive oxygen species (ROS) production and ROS elimination in the biological system caused oxidative stress. It leads to oxidative damage to cell and tissue paralleled by modifications in the morphology and function, resulting in aging and premature cell death [7]. Oxidative stress had been reported play a role in the pathogenesis and progression of diabetic tissue damage [14,43]. Index of increased oxidative stress and subsequent cytotoxicity commonly used lipid peroxidation of unsaturated fatty acid [13]. The high level of LPO is due to increased production of ROS (superoxide radicals, hydrogen peroxide and hydroxyl radicals) [36]. In our research, we investigated a significant elevation of the MDA a secondary product of LPO in STZ-induced animal. This elevated level of LPO is due to increased production of ROS (superoxide radicals, hydrogen peroxide and hydroxyl radicals).

The elevation of blood glucose levels during the experimental period clearly indicates the persistent hyperglycemia in the STZ-induced diabetic rats. However, administration with $\mathrm{MeOH}$ extract of WSSP markedly reduced the blood glucose concentration in diabetic rats. This result indicates that $\mathrm{MeOH}$ extract of WSSP acts as an antihyperglycemic agent. Moreover, the oral glucose tolerance test in the normal rat exhibited $\mathrm{MeOH}$ extract of WSSP at $120 \mathrm{~min}$ has antidiabetic activity, and showed similar effect with synthetic drug glimepiride an insulin releaser.

Hyperlipidemia has been reported to accompany hyperglycemia states $[9,25,37]$ i.e. characterized by increase in TC, LDL, VLDL, TG and fall in HDL. The marked hyperlipidemia that characterizes the diabetic states may be re- 
garded as consequence of the uninhibited actions of lipolytic hormones on the fat depots [10]. High levels of TC and more importantly LDL cholesterol are major coronary risk factors [38]. Lowering of serum lipid concentration through dietary or drug therapy seems to be associated with a decrease in the risk of vascular diseases [27]. The result of this study reveals that a daily administration of $\mathrm{MeOH}$ extract of WSSP with dose of $200 \mathrm{mg} / \mathrm{kg}$ for 2 weeks after STZ induced nearly normalized lipid profile in diabetic animals. $\mathrm{MeOH}$ extract at WSSP of dose of $200 \mathrm{mg} / \mathrm{kg}$ exhibited hypocholesterolemic and hypotriglyceridemic effect.

Several researchers have reported increases in AST and ALT activities as well as changes in lipid concentration in the serum of diabetic patients [31,33]. AST and ALT levels consider due to of liver function; hence, restoration of the normal level of AST and ALT may indicate the normalizing effect of both oral administration of MeOH extract of WSSP dose $100 \mathrm{mg} / \mathrm{kg}$ and $200 \mathrm{mg} / \mathrm{kg}$.

In analysis of thiobarbituric acid reactive substance (TBARS), our study clearly showed that MDA level was decreased in $\mathrm{MeOH}$ extract of WSSP treated diabetic rats and it may have role in scavenging hydroxyl and peroxyl radicals generated by STZ. Lipid peroxidation in DM can be considered with overproduction of oxidants or a decrease in antioxidant defenses [42]. Three antioxidant enzymes which has important function are SOD (scavenges superoxide anions), GPx (removes $\mathrm{H}_{2} \mathrm{O}_{2}$ and lipid peroxides), also CAT that are considered primary antioxidant enzymes involved in the direct elimination of ROS. According to our results, $\mathrm{MeOH}$ extract of WSSP treatment showed significant improved free radical scavenging enzymes (SOD, CAT, GPx) in the liver of STZ treated rats. SOD, CAT, and GPx are enzymes that break the peroxides and play an important role in supplying antioxidant defenses to an organism. SOD reduces superoxide to $\mathrm{H}_{2} \mathrm{O}_{2}$ that can be readily reduced to water principally by CAT and GPx [29]. The functions of these three enzymes are interconnected with the lowering of their activities resulting in the accumulation of lipid peroxides and an associated increase in oxidative stress in diabetic rats [6]. Oral administration of $\mathrm{MeOH}$ extract of WSSP improved the activities of these enzymes and thus may help protect the generation of free radicals generated during DM. The decreased activities of SOD and CAT in tissue are due to excess availability of superoxide $\left(\mathrm{O}_{2} \bullet^{-}\right)$and $\mathrm{H}_{2} \mathrm{O}_{2}$ in the biological systems, which in turn generate hydroxyl and peroxyl radicals, resulting in the initiation and propagation of lipid peroxides [25]. Meanwhile $\mathrm{MeOH}$ extract of WSSP treatment has similar effect with glimepiride produced no significant $(p>0.05)$ reduction in GST liver compared with control group. Based on the results, protective effect of $\mathrm{MeOH}$ extract of WSSP is may be due to the counteraction of free radicals throughout three antioxidant enzymes (SOD, GPx, and CAT), increasing antioxidant free radical formation, leads to reduce LPO and a significant lowering in blood glucose level. However, the precise molecular mechanism by which $\mathrm{MeOH}$ extract of WSSP exerts its protective effect against oxidative damage remains to be established. These results suggest that $\mathrm{MeOH}$ extract of WSSP administration has protective effect in STZ-induced oxidative stress in rats

In conclusion, $\mathrm{MeOH}$ extract of WSSP from Indonesia has preventive potential against many complication of diabetes by attenuating oxidative stress and hence protects organism from oxidative damage and dyslipidemia.

\section{Acknowledgement}

This reseach was supported by Kyungsung University Research Grants in 2010.

\section{References}

1. Aebi, H. 1974. Catalase, pp. 673-684, In Bergmeyer, H. U. (ed.), Method of Enzymatic Analysis. 2, Academic press, New York.

2. Attele, A. S., Y. P. Zhou, J. T. Xie, J. A. Wu, L. Zhang, L. Dey, W. Pugh, P. A. Rue, K. S. Polonsky, and C. S. Yuan. 2002. Antidiabetic effects of Panax ginseng berry extract and the identification of an effective component. Diabetes 51, 1851-1858.

3. Baynes, J. W. and S. R. Thorpe. 1997. The role of oxidative stress in diabetic complications. Curr. Opin. Endocrinol. 3, 277-284.

4. Baynes, J. W. 1991. Role of oxidative stress in the development of complications in diabetes. Diabetes 40, 405-412.

5. Bernhard, L., W. Werner, P. Rudolf, K. W. Alexandra, and P. Giovanni. 2003. Mode of action of Ipomoea Batatas (Caiapo) in type 2 diabetic patients. Metabolism Clinical and Experimental 52, 875-880.

6. Chaudhry, J., N. N. Ghoxh, K. Roy, and R. Chandra. 2007. Antihyperglycemic effect of a new thiazolidine analogue and its role in ameliorating oxidative stress in alloxan-induced diabetic rats. Life Sci. 80, 1135-1142.

7. Craik, F. I. M. and T. A. Salthouse. 1992. Handbook of Ageing and Cognition, pp. 51-110, Hillsdale, New Jersey.

8. FAO, 2006. http://www.fao.org, cited: 15/10/2006. 
9. Garber, A. J. 2002. Attenuating CV risk factors in patients with diabetes: clinical evidence to clinical practice. Diabetes, Obesity and Metabolism 4, S5-S12.

10. Goodman, L. S. and A. Gilman. 1985. The Pharmacological basis of therapeutics. pp. 1490-1510, 7th eds., Macmillan, New York.

11. Grover, J. K., S. Yadav, and V. Vats. 2002. Medicinal plants of India with anti-diabetic potential. Journal of Ethnopharmacology 81, 1-100.

12. Habig, W., M. J. Pabst, and W. B. Jakoby. 1974. Glutathione S-transferases the first enzymatic step in mercapturic acid formation. J. Biol. Chem 249, 7130-7139.

13. Hauggard, N. 1968. Cellular mechanism of oxygen toxicity. Physiol. Rev. 48, 311-373.

14. Hiramatsu, K. and S. Aomori. 1988. Increased superoxide production by mononuclear cells of patients with hypertriglyceridemia and diabetes. Diabetes 37, 832-837.

15. Huang, G. J., H. Y. Chang, H. J. Chen, T. L. Lu, Y. S. Chang, M. J. Sheu, and Y. H. Lin. 2008. Effects of trypsin inhibitor on plasma antioxidant activity and lipid levels in mice from sweet potato roots. J. Sci. Food Agric. 88, 2556-2562.

16. Huang, Y. C., Y. H. Chang, and Y. Y. Shao. 2005. Effects of genotype and treatment on the antioxidant activity of sweet potato in Taiwan. Food Chemistry 98, 529-538.

17. Kakkar, R., J. Karla, S. V. Manth, and K. Parsad. 1995. Lipid peroxidation and activity of antioxidant enzymes in diabetic rats. Mol. Cell Biochem 151, 113-119.

18. Kano, M., T. Takayanagi, K. Harada, K. Makino, and F. Ishikawa. 2005. Antioxidant activity of anthocyanins from purple sweet potato, Ipomoea batatas cultivar Ayamurasaki. Biosci. Biotechnol. Biochem 69, 979-988.

19. Laakso, M. 2001. Insulin resistance and its impact on the approach to therapy of type 2 diabetes. Int. J. Clin. Pract. Supplemen 8-12.

20. Marklund, S. and G. Marklund. 1974. Involvement of the superoxide anion radical in the autoxidation of pyrogallol and a convenient assay for superoxide dismutase. Eur. J. Biochem 47, 469

21. McGowan, M. W., J. D. Artiss, and D. R. Stradbergh. 1983. A peroxidase coupled method for the colorimetric determination of serum triglycerides. Clin. Chem 29, 583.

22. Ohkawa, H., N. Ohishi, and K. Yagi. 1979. Assay for lipid peroxides in animal tissues by thiobarbituric acid reaction. Analytical Biochem 95, 351-358.

23. Oki, T., M. Masuda, S. Furuta, Y. Nishiba, N. Terahara, and I. Suda. 2002. Involvement of anthocyanins and other phenolic compounds in radical scavenging activity of purple-fleshed sweet potato cultivars. J. Food Sci. 67, 1752-1756.

24. Paglia, E. D. and W. N. Valentine. 1967. Studies on the quantitative and qualitative characterization of erythrocyte glutathione peroxidase. J. Lab. Clin. Med 70, 158-169.

25. Randle, P. J., P. B. Gailand, C. N. Hales, and E. A. Neiosholine. 1963. The glucose and fatty acid cycle: its role in insulin sensitivity and metabolic disturbance of diabetes. The Lancet 1, 785-790.

26. Reitman, S. and S. Frankel. 1957. A colorimetric method for the determination of serum glutamic oxalacetic and glutamic pyruvic transaminases. Am J. Clin. Pathol. 28, 56-63.

27. Rhoad, G. G., C. L. Gulbrandse, and A. Kagen. 1976. Serum lipoprotein and coronary artery disease in a population study of Hawaiian Japanese men. New England J. Medicine 294, 293-298.

28. Richmond, W. 1976. Use of cholesterol oxidase for assay of total and free cholesterol in serum by continuous flow analysis. Clin. Chem 22, 1579.

29. Robertson, R. P., J. Harmon, P. P. Tran, Y. Tanaka, and H. Takahashi. 2003. Glucose toxicity in $\beta$-cells: type 2 diabetes, good radicals gone bad, and the glutathione connection. Diabetes 52, 581-587.

30. Rully, M. 1988. Pengaruh infus batang ubi jalar (Ipomoea batatas Poir) sebagai antidiabetik pada binatang percobaan tikus. JF FMIPA UNHAS 109.

31. Ruzaid, A., I. Amin, A. G. Nawalyah, M. Hamid, and H. A. Faizul. 2005. The effect of Malaysian cocoa extract on glucose levels and lipid profiles in diabetic rats. $J$. Ethnopharmacol. 98, 55-60.

32. Shuichi, K., A. Hiroyuki, and T. Hirohide. 2001. Isolation of antidiabetic components from white-skinned sweet potato (Ipomoea batatas L.). Biosci. Biotechnol. Biochem 65, 109-114.

33. Singh, N., V. Kamath, and P. S. Rajini. 2005. Attenuation of hyperglycemia and associated biochemical parameters in STZ-induced diabetic rats by dietary supplementation of potato peel powder. Clin. Chim Acta. 353, 165-175.

34. Stefek, M., N. Tribulova, A. Gajdoski, and A. Gajdosikova. 2002. The pyridoindole antioxidant stobadine attenuates histochemical changes in kidney of STZ-induced diabetic rats. Acta Histochem 104, 413-417.

35. Szkudelski, T. 2001. The mechanism of alloxan and streptozotocin action in $\beta$-cells of the rat pancreas. Physiol. Res. 50, 537-546.

36. Tarique, A., M. Sharma, K. K. Pillai, S. E. Haquea, M. M. Alam, and M. S. Zaman. 2007. Protective effect of bezafibrate on streptozotocin-induced oxidative stress and toxicity in rats. Toxicology 229, 165-172.

37. Taskinen, M. R. 1993. Lipoprotein and apoproteins in diabetes. pp. 122-134, In Belfiore, F., R. N. Bergnan, and G. M. Molinatt (eds.), Current Topics in Diabetes Research 12. Informa Health Care.

38. Temme, E. H., H. P. G. Van, E. G. Schouten, and H. Kesteloot. 2002. Effect of a plant sterol-enriched spread on serum lipids and lipoprotein in mildly hypercholesterolaemic subjects. Acta Cardiology 57, 111-115.

39. Teow, C. C., V. D. Truong, R. F. McFeeters, R. L. Thompson, K. V. Pecota, and G. C. Yencho. 2007. Antioxidant activities, phenolic and $\beta$-carotene contents of sweet potato genotypes with varying flesh colours. Food Chemistry 103, 829-838.

40. Toshiro, M., E. Sumi, K. Mio, F. Keiichi, S. Koichi, T. Norihiko, and M. Kiyoshi. 2002. Anti-hyperglycemic effect of diacylated anthocyanin derived from Ipomoea batatas Cultivar Ayamurasaki can be achieved through the a -glucosidase inhibitory action. J. Agric. Food Chem. 5, 7244-7248. 
41. Uchida, T., R. Tsuchiya, N. Harada, T. Tsunoda, T. Yamaguchi, T. Eto, and M. Furukawa. 1988. Ischemic changes in the pancreas of Watanabe heritable hyper-lipidemic (WHHL) rabbits. Int. J. Pancreato. 3, 261-271.

42. Ugochukwu, N. H., N. D. Bagayoko, and M. E. Antwi. 2004. The effects of dietary caloric restriction on antioxidant status and lipid peroxidation in mild and severe streptozotocin-induced diabetic rats. Clin. Chim Acta. 348, 121-129.

43. Wolff, S. P., Z. Y. Jang, and V. J. Hunt. 1991. Protein glycation and oxidative stress in diabetes mellitus and ageing.
Free Radic. Biol. Med 10, 339-352.

44. Yamagishi, N., K. Nakayama, T. Wakatsuki, and T. Hatayama. 2001. Characteristic changes of stress protein expression in streptozotocin induced diabetic rats. Life Sci. 9 , 2603-2609.

45. Zhang, Z. F., S. H. Fan, Y. L. Zheng, J. Lu, D. M. Wu, Q. Shan, and B. Hu. 2009. Purple sweet potato color attenuates oxidative stress and inflammatory response induced by D-galactose in mouse liver. Food and Toxicology 47, 496-501.

\section{초록 : 흰 쥐에서 streptozotocin으로 유발된 산화적 스트레스에 대한 인도네시아산 white-skinned sweet potato (WSSP, Ipomoea batatas L.)의 보호효과}

Moch, Saiful Bachri · 장혜원 ${ }^{1} \cdot$ 최종원 ${ }^{2} \cdot$ 박종옥 $^{3}$ *

(인도네시아 아마드 달란대학교 약제부, ${ }^{1}$ 성균관대학교 의과대학 삼성서울병원 내분비내과, ${ }^{2}$ 경성대학교 약학대학 약학과, ${ }^{3}$ 경성대학교 화학과)

White-skinned sweet potato (WSSP, Ipomoea batatas L.)는 인도네시아 및 다른 나라 등에서 전통약제로 당뇨병 치료에 널리 사용되고 있다. 본 실험에서는 흰 쥐를 streptozotocin $(45 \mathrm{mg} / \mathrm{kg}$ 체중, i.p.)으로 당뇨병을 유발시킨 후 WSSP의 메탄올 추출물을 체중 $1 \mathrm{~kg}$ 당 Dose $100 ; 200 \mathrm{mg} / \mathrm{kg}$ 을 경구로 투여하였다. 산화적 스트레스에 대한 보호효과를 평가하였고 그 효능을 인슐린 분비촉진제인 glimepiride $(50 \mathrm{mg} / \mathrm{kg}$ 체중 $)$ 와 비교해 보았다. 산화적 스트레스 평가는 WSP 메탄올 추출물과 glimepiride를 2주 투여 한 후 간장조직의 지질 과산화물(LPO)함량, 혈청 AST, ALT, total triglyceride (TG), total cholesterol (TC), 그리고 항산화효소들인 superoxide dismutase (SOD), 카탈라아제 $(\mathrm{CAT})$, 글루타치온 과산화물 분해효소(GPx), 글루타치온 S-전이효소(GST)활성도 등을 간장에서 측정 하여 시행하였다. 당뇨 흰쥐에서 혈당, $\mathrm{LPO}$ 함량, $\mathrm{AST}, \mathrm{ALT}, \mathrm{TG}, \mathrm{TC}$ 함량 등은 정상군에 비하여 그 값이 증가하 였고, SOD, CAT, GPx, GST 활성도 값은 감소하였다. 당뇨 흰쥐에 WSSP 메탄올 추출물 $(200 \mathrm{mg} / \mathrm{kg})$ 을 2주일 동안 투여한 결과 의미있는 혈당 감소를 볼 수 있었고, $\mathrm{LPO}, \mathrm{TG}, \mathrm{TC}, \mathrm{AST}, \mathrm{ALT}$ 함량에서도 개선효과를 볼 수 있었다. 또한 SOD, GPx, 그리고 CAT등 항산화효소들의 활성도 증가도 나타났다. 따라서 WSSP 메탄올 추출물은 당뇨쥐의 혈당을 낮추어 산화적 스트레스를 약화시키고 당뇨로 유발된 손상을 보호해 주는 효과가 있다는 결과 를 얻었다. 